\title{
Constructed Ponds and Small Stream Habitats: Hypothesized Interactions and Methods to Minimize Impacts
}

\author{
Jonathan D. Ebel ${ }^{1,2}$, Winsor H. Lowe ${ }^{1}$ \\ ${ }^{1}$ Division of Biological Sciences, University of Montana, Missoula, USA \\ ${ }^{2}$ Biology Department, Memorial University of Newfoundland, St. John’s, Canada \\ Email: jd.ebel@mun.ca
}

Received April 28, 2013; revised May 29, 2013; accepted June 21, 2013

Copyright (C 2013 Jonathan D. Ebel, Winsor H. Lowe. This is an open access article distributed under the Creative Commons Attribution License, which permits unrestricted use, distribution, and reproduction in any medium, provided the original work is properly cited.

\begin{abstract}
Extensive research has been conducted on how large impoundments and reservoirs affect hydrologic, geomorphologic and ecological processes in downstream ecosystems. Surprisingly, few studies have addressed the effects of smaller impoundments and constructed ponds. Pond construction has been considered an important tool for managers seeking to reduce sediment, nutrient and pollutant loads, and increase habitat heterogeneity in streams in an effort to conserve or enhance aquatic species diversity. However, we lack information on the interaction between ponds and stream habitats, which may compromise the efficacy of conservation efforts. The objective of this review is to outline possible physical and biological changes to stream ecosystems resulting from pond construction. Greater understanding of how ponds influence watershed processes at various spatial scales is crucial to evaluating the effects of constructed ponds on stream ecosystems.
\end{abstract}

Keywords: Headwater Streams; Discharge; Nutrient Retention; Spatial Scale; Lotic; Lentic

\section{Introduction}

Research on the effects of large impoundments on downstream ecosystems has largely focused on reservoirs and rivers. Numerous studies have shown that impoundments cause drastic changes in ecosystem structure throughout watersheds and even continents by changing numerous ecological, hydrologic, and geomorphic processes [1,2]. At smaller scales, stream ecologists have long been interested in the effect of wetlands and beaver impoundments on stream fishes, aquatic macroinvertebrates, water chemistry and geomorphic characteristics [3,4]. Lakestream interactions have been recently reviewed in an attempt to guide future research on incorporating lakes into the river continuum [5]. However, little research has addressed the interaction of human-constructed ponds and adjacent streams, despite the global proliferation of small impoundments and diversions and an increase in the number and geographic extent of anthropogenic ponds [2].

Ponds number in the millions worldwide [2]. At the continental scale, ponds may play a measurable role in the global carbon cycle [6] and sediment movement [2]. At regional and watershed scales, ponds can reduce stream sediment loads and nutrient concentrations [7]. It is well documented that pond construction can benefit regional biodiversity by increasing freshwater habitat heterogeneity [8]. Furthermore, ponds can support a range of recreational activities for humans, be used to improve water quality, and provide other important ecosystem services. Overall, the construction of ponds within highly degraded or biologically depauperate watersheds can be a beneficial prescription. Yet, we know little of how ponds alter stream ecosystem dynamics, especially in relatively undisturbed watersheds.

Despite the recent proliferation of artificial ponds within watersheds throughout the United States, there is limited literature examining the effect of these ponds on in-stream habitat. The current lack of understanding of pond-stream interactions underscores the need to provide a synthetic framework to guide future research and management of watersheds with respect to the construction, placement, and maintenance of constructed ponds. In this synthesis, we provide a broad examination of the effects 
of constructed ponds on in-stream habitat. We focus this discussion on hypothesized alteration of physical and biotic processes in adjacent streams because stream habitat is formed, maintained, and altered by the reciprocal interactions of these processes. This review is purposely interdisciplinary because of the inherent complexity of the topic. Our primary goal is to step back from the details of in-pond dynamics in order to call attention to broader patterns of pond-stream interactions and to identify specific points of relevance to conservation and management.

Streams integrate landscape properties in a hierarchical fashion, moving from network, to stream, to reach, to habitat $[9,10]$. Our vision of the interaction of ponds and streams applies hierarchical patch dynamic [11] and network dynamic [12] perspectives of the river continuum. Specifically, we suggest that the effect of constructed ponds on streams depends heavily on pond density at the network scale and individual pond design at the stream, and habitat scales (Figure 1). While pond design is designated by landowners and tends to lie within the confines of regional and federal regulations, pond density within a stream network depends on the dominant land use and the aggregative (and possible cumulative) actions of many landowners.

\section{Terminology}

Constructed ponds are highly diverse with respect to their purpose, design, water storage capacity, catchment characteristics (i.e., surrounding land use, vegetation) and biota. As a result of this diversity, ponds are difficult to define. We define constructed ponds as man-made

Network Scale

- Reduced sediment load

- Reduced stream flow

Stream Scale

- Alters floodplain characteristics

- Changes nutrient transport and storage processes

- Dampens peak flows

Habitat scale

- Increases benthic substrate size

- Alters temperature regime

- Drastic changes to channel morphology

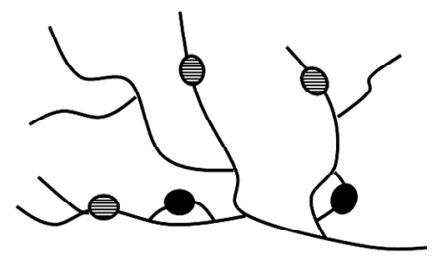

Figure 1. Multiple scales of physical and chemical consequences of constructing on-stream (hatched) and off-stream (black) ponds for small stream habitats. water bodies with areas between $10 \mathrm{~m}^{2}$ and $60,000 \mathrm{~m}^{2}$ that hold water throughout the year. To further restrict the types of waterbodies discussed here, we will focus on those ponds that gain water through the direct impoundment or diversion of surface flow, rather than solely rainfall and/or groundwater. Diversion-fed ponds are often built by landowners and government agencies to serve a variety of purposes, including water supply for livestock, sediment trapping, erosion control, nutrient removal, recreation, and aesthetic improvement [13].

In this context, we can place constructed ponds in one of two categories; 1 ) on-stream ponds-built by impounding the existing stream channel and causing an abrupt shift from lotic to lentic habitat where the stream enters the pond and from lentic to lotic at the impoundment, and 2) off-stream ponds, which require the diversion of part of total stream discharge and are located in the floodplain adjacent to the stream channel (Figure 1).

On-stream ponds can be viewed as a single patch within a stream network, as conceptualized by hierarchical patch dynamic perspective of the river continuum [11]. According to this perspective, a stream is comprised of hierarchically nested patches arranged longitudinally in space. Patches have unique community and biogeochemical structures and functions that vary with time, although the dynamics of individual patches are not independent of other patches. Therefore, biological and chemical fluctuations within an upstream patch can alter the dynamics of downstream patches.

Off-stream ponds alter stream network structure by removing flow at the point of diversion, much like a braided channel, and creating a confluence at the point where the effluent discharge channel joins the stream. Here, we apply a network dynamics perspective because braids and confluences can cause locally abrupt changes in water chemistry and sediment flux while also altering channel and floodplain characteristics [12]. At the network scale, the number and arrangement of off-stream ponds interact with the natural stream to influence the diversity of stream habitat patches by the accumulation of local changes to biogeochemical and geomorphological characteristics.

\section{Alterations of Physical Conditions}

\subsection{Flow Regime}

The residence time and amount of water in ponds may reduce temporal variation in stream discharge, mimicking the flow regimes downstream of mountain lakes and beaver ponds. Residence time is calculated as the volume of the pond divided by inflow per unit time. In snowmelt dominated lake-stream systems, the retention of water in a lake reduces the magnitude and increases the duration of over-bank flooding events downstream [14]. The 
downstream flow regime is dictated by the water level in the lake. Beaver ponds also dampen peak flows and increase low flows [15]. Despite the highly variable outlet structures of on-stream ponds, water level relative to outlet elevation remains the dominant control of discharge. Off-stream ponds should have more variable effects on flow regimes, mainly the magnitude and duration peak flows. We predict the degree to which off-stream ponds alter flow regimes to be a function of the percentage of flow diverted into the pond and the ratio of undiverted flow to effluent discharge.

At the watershed scale, the ratio of constructed pond/ wetland area to total watershed area is one of the most important factors determining the capacity of a watershed to decelerate high stream flows [16]. At the scale of individual ponds and the adjacent stream, deceleration of flow and sediment trapping capacity depends on residence time of the pond. Variation in residence times among ponds of similar volume and inflow rate is partially attributed to differences in hydraulic efficiency, defined as the efficiency with which the volume of the pond is utilized [17]. Features that improve the hydraulic efficiency of constructed ponds include an elongated shape, submerged terraces, baffles and islets [17]; all of which act to distribute the energy of inflowing water throughout the pond and minimize sediment re-suspension events during high flows [18]. With respect to suspended sediments, higher residence times in the pond allows more suspended sediments to settle out of the water column. Pond designs with long residence times coupled with high hydraulic efficiencies should have the largest effect on natural flow regimes and sediment loads, with consequences for substrate characteristics and habitat complexity in receiving streams.

\subsection{Sediment Load and Habitat Complexity}

By decelerating flow and allowing suspended particles to settle out of the water column, ponds reduce the load of fine sediments downstream by acting as a sediment sink. Discontinuity of sediment loads due to lentic habitat patches can have profound effects on physical attributes of downstream segments. For example, a study characterizing the influence of glacial lakes on the physical form and function of mountain streams in central Idaho, USA, found that sediment size, channel shape, and sediment entrainment is best described by the location of sediment sources (e.g., hillslopes and tributaries) and sinks (e.g., lakes) because fine sediments are removed and downstream flow regime is altered [19]. Because elevated sediment loads in streams often have negative effects on stream organisms [20], ponds have been prescribed as a conservation tool to lower suspended sediment concentrations in watersheds disturbed by agricultural development, road construction, or fires [18].
In relatively undisturbed streams, the relationship between suspended sediment load and discharge is viewed as a dynamic equilibrium that can be disrupted by changes in either sediment load or discharge [21]. Constructed ponds can alter the suspended-sediment discharge relationship by 1) changing the discharge regime by diverting flow and increasing water residence time at the pond location, 2) changing channel morphology by building impoundments, diversion and effluent channels, and the pond itself, and 3) slowing the downstream transport of bed load materials and suspended sediment from sources upstream in the watershed.

While used as a measure of success for restoration projects in many disturbed watersheds, drastically lowered sediment loads in undisturbed watersheds disrupt the relationship between the load and size of sediments (i.e., supply) and stream power-a function of streamflow discharge, water surface slope, and the specific weight of water. Channel degradation, or the localized removal of channel bed material by stream water without adequate deposition, occurs when stream power exceeds the sediment supply [21], and can lead to channel incision and streambed armoring [28]. The magnitude and extent of channel degradation depends heavily on the location of new sources of sediment downstream. Channel incision below off-stream ponds can be easily avoided by constructing a low gradient effluent channel with low water surface slope.

Streambed armoring occurs when only small particles are entrained and the resulting streambed consists of large substrates that are immobile during bank-full flows [19]. We predict that armoring below on-stream ponds and some off-stream ponds is more likely to occur than channel incision because it is more difficult for landowners to maintain the supply of small sediments to the downstream streambed at pre-pond levels. In most cases, small sediment supply will be negligible immediately below on-stream ponds and greatly reduced below offstream ponds with high ratios of diverted stream discharge to un-diverted stream discharge and effluent discharge to receiving stream discharge.

\subsection{Temperature}

The direct discharge of high temperature water from a pond into a stream can increase temperatures of the receiving stream to above normal levels [22]. Excellent literature reviews exist that explore the fundamental controls on stream water temperature [23] and biological responses to temperature variation [24]. We suggest four important factors that interact to influence in-pond water temperatures and consequent effects of effluent discharge on the temperature regimes of receiving streams: 1 ) the placement of a pond within a watershed, 2) the surface area to volume ratio of the pond, 3) light penetration into 
the pond, and (4) residence time of stream water in the pond.

Pond surface area to volume ratio $(\mathrm{SA}: \mathrm{V})$ governs the efficiency of radiant heating and water column mixing [25] because the exposure of a pond to radiant energy and wind increases with surface area. Pond depth influences light penetration and whether wind mixing will affect the hypolimnion. Differences in light penetration among ponds leads to variation in radiant heating of ponds with similar SA:V. Light penetration is influenced primarily by aquatic macrophyte coverage and pollution [26]. The heated water is then discharged from the pond back into a stream, altering downstream temperatures during summer months when low flows and high temperatures already may cause harm at a critical time in the life histories of stream organisms [27].

In general, ponds fed by headwater streams tend to be much cooler than ponds fed by larger streams in the same system [28]. Because ponds have a greater thermal inertia than small streams, warmer water temperatures may persist in ponds into the autumn months. The steepest temperature gradients in a stream-pond network occur at pond-stream transitions, and the gradient between upstream and downstream temperature is steeper for onstream ponds as opposed to off-stream ponds. An example of the former is described by Maxted et al. [22], who observed higher mean daily stream temperatures throughout the summer and autumn in streams below onstream ponds in New Zealand, especially below ponds lacking riparian canopy cover. Similarly, Jones and Hunt [29] found that off-stream ponds acted as point sources of thermal pollution. In some ponds, however, substantial input of stable temperature groundwater can reduce diel temperature ranges and keep ponds cooler than the adjacent stream regardless of a ponds location in a watershed (Ebel and Lowe, unpublished data).

Changes in water temperature have consequences for the lotic communities and ecosystem processes by limiting dissolved oxygen concentrations, influencing the feeding and metabolic rates of stream organisms and altering microbially mediated nutrient cycling [30]. In streams dominated by species that require low, stable water temperatures, like many in the Northern Rocky Mountains, water temperatures exceeding $20^{\circ} \mathrm{C}$ lead to decreased growth rates and survival of salmonids [31]. On-stream ponds will likely cause an abrupt change in temperature and biotic community structure [1] along a longitudinal gradient encompassing the pond and adjacent upstream and downstream reaches. The direction of the temperature gradient depends on whether pond effluent is released from the surface (warmer effluent) or from the bottom of the pond (colder effluent). The effect of off-stream ponds with regulated headgates [32] will likely be less than on-stream ponds, and should vary seasonally depending on the amount of inflow, residence time of water in the pond, and the ratio of effluent flow and temperature to mainstem flow and temperature [33]. We hypothesize that discharge from off-stream ponds affects stream temperatures more when those ponds are located along lower-order headwater streams with lower flows and higher pond-to-stream temperature ratios.

The most effective strategy to prevent artificial increases in stream temperature from pond effluent is to prevent pond temperatures from reaching levels beyond the tolerances of native stream organisms. This can be accomplished by designing ponds with low surface area to volume ratios, altering outlet structures such that effluent is drawn from the lower strata of the pond, or minimizing the ratio of effluent discharge to receiving stream discharge.

\section{Alteration of Chemical Conditions}

The creation of standing water along a stream changes the downstream transport of nutrients. For this reason, pond construction is a common technique used by environmental engineers and stream restoration practitioners [7]. Summarizing the nutrient chemistry of ponds is made difficult by the range of pond designs, the varying sources of nutrients from the atmosphere and watershed, intricacies of nitrogen and phosphorous dynamics within ponds, and widely differing water retention times. The details of these processes have been extensively reviewed elsewhere [34]. It is well understood that ponds can improve the water quality of streams degraded by intensive mining and sewage treatment plant effluent; however, changes to the chemical cycling of currently unimpacted streams may alter microbially mediated chemical cycling with unintended consequences for intact lotic food webs and must be considered during watershed planning. Overall, the degree to which a constructed pond will influence streamwater chemistry is design and region dependent, requiring pond architects to have in-depth knowledge of watershed characteristics if in-stream effects are to be minimized.

Phosphorous (P) sorption and desorption in aquatic systems are governed by the structure of sediment particles, the degree of phosphate saturation, and sensitivity to environmental changes [35]. Pond sediments can be a temporary phosphorous sink and provide an important ecosystem service, especially in agricultural areas, by reducing phosphate concentrations downstream. A Swedish study estimated that a constructed, open water wetland retained $17 \%$ of mean annual P load over 4 years, with $78 \%$ of retained $\mathrm{P}$ held in sediments close to the inlet [36]. Retained P in this wetland was predominately in potentially mobile forms; i.e., organic $\mathrm{P}$ and $\mathrm{P}$ associated with iron or aluminum. Potentially mobile implies that $\mathrm{P}$ can be released from sediments. P-release from 
sediments into pond effluent depends on the sediment phosphate capacity and varies seasonally because warming water temperatures can promote phosphate release by the increasingly anoxic conditions at the sediment-water interface associated with increased microbial activity [37]. Released phosphates can be exported to adjacent streams through pond effluent. Such pulses of phosphates can be especially harmful to headwater systems where phosphate concentrations will depend mainly on effluent discharges since background concentrations are close to detection limits [35]

In headwater streams, the majority of energy driving the system is derived from allochthonous sources [28]. Impoundments greatly depress the ratio of course particulate organic matter to fine particulate organic matter as the downstream movement of detritus is blocked and phytoplankton and fine sediments is discharged from the pond. Nutrient loading of ponds and nutrient discharges can stimulate in situ production by in-pond phytoplankton communities and in-stream biofilms possibly altering the trophic state of the recipient stream [38]. Discharge of pond autotroph biomass (either dead or alive) can change the energy dynamics of downstream communities by shifting the predominant source of utilizable carbon from recalcitrant leaf litter to labile algal photosynthates. This shift in major energy source would cause changes in downstream macroinvertebrate community assemblage and production.

Well placed, designed, and managed ponds can play a critical role in the removal of nitrogen from streamwater, but can discharge retained nitrogen under some conditions. Pond construction can stimulate nitrogen removal by providing the anaerobic conditions necessary for denitrification pathways. Total nitrogen removal often varies between $40 \%$ and $55 \%$ of total input depending on the design of the pond or wetland and nitrate loading rate. Nitrate not removed through denitrification is transformed and retained by burial and sorption to sediments and is thus available to be discharged during high flow events, pond dredging, or outflow control failures. Such nitrogen pulses can cause changes in downstream biotic communities. For example, Selong and Helfrich [39] found that overall macroinvertebrate species richness decreased below constructed trout ponds. The reduction in overall species richness was accompanied by a decrease in the ratio of mayflies, stoneflies, and caddisflies to chironomids, and the ratio of shredders to the total insects. They attributed the shift in the macroinvertebrate community to increased nitrogen levels caused by high concentrations of nutrients in off-stream pond effluent during pond-dredging events and pond nutrient enrichment by trout feeding loads.

\section{Biotic Changes}

Research on ponds and biodiversity is rapidly increasing, showing that ponds increase regional biodiversity and promote rare aquatic species [40]. Specific management techniques to maximize pond biodiversity have been reviewed [8]. The arrangement and size of constructed ponds within a watershed can influence the effectiveness of pond construction as a tool for biodiversity conservation. For example, Oertli et al. [41] found that many small ponds in close proximity to each other can support greater regional biodiversity than a few large ponds. Furthermore, the creation of areas of high pond density that provide increased habitat complexity and maintains high among-pond connectivity can help to sustain persistent metapopulations of rare species [41]. However, the benefits of pond construction aimed at protecting rare lentic species should be weighed against the possible costs of de-stabilizing intact stream ecosystems.

Habitat alterations and subsequent biological invasions are cited as two major drivers of biodiversity loss worldwide. Clearly, the excavation of a pond causes a drastic change in the local biotic community on the floodplain by creating lentic habitat where it did not previously exist. Increases in invader abundance typically follow any natural or anthropogenic disturbance [42] and the disturbed floodplains and streams provide a prime opportunity for invader establishment. In addition to the susceptibility of newly-constructed ponds to biological invasions, constructed ponds also can pose a threat to native species assemblages in adjacent streams by decreasing the ability of stream communities to resist invasions.

An invader of increasing importance to the health of streams in the western USA is Myxobolis cerebralis, an invasive myxosporean parasite identified as the cause of whirling disease in salmonid species. Allen and Bergersen [43] found the highest densities of Tubifex tubifex, the invertebrate host of $M$. cerebralis, in the Poudre Rearing Unit (PRU) of the Cache la Poudre River in Colorado, a trout rearing facility consisting of a series of off-stream ponds. T. tubifex densities were three orders of magnitude higher in the PRU than in all alcoves and eddies along the stream reach. Similar results were found on the Salt River, Wyoming [44], and the Fryingpan River, Colorado [45], where ponds served as point sources of infectious triactinomyxons (spore emitted into the water column by the invertebrate host; TAMs).

Measures of juvenile rainbow trout infection and recruitment rates, as well as densities of infected T. tubifex, indicate that the complete infection of all salmonids in a system requires very few $T$. tubifex and TAMs. Outbreaks of whirling disease greatly reduce salmonid recruitment in cold, oligotrophic, sediment poor, high gradient streams [43], especially during times of decreased stream flow [46]. Several techniques have been used to decrease the concentrations of TAMs in pond effluent, the most efficient being sand filtration [45]. As a severe 
threat to wild salmonid populations across the western United States, more information is needed on the role of on- and off-stream ponds in the spread and severity of whirling disease outbreaks.

Increases in physical heterogeneity of stream systems can cause variation in colonization, persistance and dispersal of both vertebrates and invertebrates. For example, Schlosser [4] concluded that discharge-mediated interactions between beaver ponds and streams benefited creek chub populations (Semotilus atromaculatus) by controlling fish dispersal, fish diversity, fish predation, and macroinvertebrate community composition (e.g., densities in riffles vs. pools during high and low discharge). Knutson et al. [47] came to a similar conclusion, relating the persistence of amphibian populations to the increase in breeding habitat as a result of pond construction. In contrast, Olsson et al. [48] found that the physical habitat alteration associated with constructed ponds caused increased mortality of migrating brown trout smolts (Salmo trutta) in Sweden. They attributed this increase in smolt mortality to the shift to standing water habitat, causing changes in downstream migration speed and exposing smolts to increased levels of predation. In this case, anthropogenic changes to the physical heterogenity of streams had a negative effect on recruitment because the specific population of brown trout had not evolved to survive in standing water habitats.

\section{Conclusions and Future Challenges}

Constructed ponds have situation-specific effects on adjacent streams; a single pond may alter physiochemical and biotic conditions at scales ranging from local habitats to entire stream segments. In lower order drainages with high pond density, the cumulative effects of on and/or off-stream ponds may alter entire watersheds. Decisions on whether to construct ponds along streams and how to manage existing ponds must be evaluated based on the broader goals of human communities within the watershed, as well as management and conservation objectives of local, state, and federal governmental entities. There is a mismatch between the proliferation of constructed ponds and the current state of empirical knowledge regarding the myriad of possible consequences for stream ecosystems. Small-scale and short-term studies are inadequate because they fail to accurately identify threats and critical scales of management [49].

Pond construction and management must delicately balance recreational and economic needs while minimizing alterations or disturbances to adjacent stream ecosystems. Before effective policy for pond construction can be implemented, it is imperative that we answer the following questions:

1) What types of streams and geographical regions are most susceptible to the negative effects of constructed ponds?

2) Can pond design and management protocols overcome negative effects on sensitive streams or regions? What designs and protocols are most effective?

3) How many ponds along a stream are necessary to achieve restoration or mitigation goals while minimizing negative or cumulative effects on in-stream habitats?

Although the design and placement of a pond is watershed-specific, a well-designed pond should achieve two objectives: 1) increase the biodiversity of a watershed by providing increased aquatic and riparian habitat complexity and valuable ecological services (e.g., sediment trapping, nutrient retention) and 2) minimize negative effects on natural stream processes and habitat.

Many questions about pond-stream interactions remain unanswered, illustrating our limited understanding of interactions among aquatic ecosystems and how these interactions should influence management decisions. Although some researchers suggest that the construction of ponds should be encouraged because they can facilitate the persistence of rare aquatic species and increase the biodiversity of a watershed [8], pond construction can also pose serious threats to the overall ecological health of a watershed. Processes resulting from the interaction of constructed ponds and nearby streams are varied and complex. Our understanding of these interactions would benefit from quantification of downstream changes in the physical, chemical and biological variables discussed in this review in a Before-After-Control-Impact study framework [50] Furthermore, the recognition that material processing within pond and stream habitats is spatially dependent will provide the means to place constructed ponds in the context of entire landscapes [51]. The connection of ecological processes of constructed ponds to stream habitats is essential to pond management practices that maintain the biological integrity of watersheds.

\section{Acknowledgements}

This review was supported by funding from the Rock Creek Trust and Five Valley Land Trust, Missoula, MT, Montana NSF EPSCoR, and the Howard Hughes Medical Institute through the MILES program.

\section{REFERENCES}

[1] J. A. Stanford and J. V. Ward, "Revisiting the Serial Discontinuity Concept," Regulated Rivers: Research and Management, Vol. 17, No. 4-5, 2001, pp. 303-310. doi:10.1002/rrr.659

[2] J. A. Downing, "Emerging Global Role of Small Lakes and Ponds: Little Things Mean a Lot,” Limnetica, Vol. 29, No. 1, 2010, pp. 9-24.

[3] R. J. Naiman, J. M. Melillo and J. E. Hobbie, "Ecosystem Alteration of Boreal Forest Streams by Beaver (Castor 
canadensis),” Ecology, Vol. 67, No. 5, 1986, pp. 12541269. doi:10.2307/1938681

[4] I. J. Schlosser, "Dispersal, Boundary Processes and Trophic-Level Interactions in Streams Adjacent to Beaver Ponds,” Ecology, Vol. 76, No. 3, 1995, pp. 908-925. doi:10.2307/1939356

[5] N. E. Jones, "Incorporating Lakes Withing the River Discontinuum: Longitudinal Changes in Ecological Characteristics in Stream-Lake Networks," Canadian Journal of Fisheries and Aquatic Sciences, Vol. 67, 2010, pp. 13501362. doi:10.1139/F10-142

[6] J. A. Downing, Y.T. Prairie, J. J. Cole, C. M. Duarte, L. J. Tranvik, R. G. Striegl, W. H. McDowell, P. Kortelainen, N. F. Caraco, J. M. Melack and J. J. Middelburg, "The Global Abundance and Size Distribution of Lakes, Ponds, and Impoundments," Limnology and Oceanography, Vol. 51, No. 5, 2006, pp. 2388-2397. doi:10.4319/lo.2006.51.5.2388

[7] K. G. Taylor and P. N. Owens, "Sediments in Urban River Basins: A Review of Sediment-Contaminant Dynamics in an Environmental System Conditioned by Human Activities,” Journal of Soils and Sediments, Vol. 9, No. 4, 2009, pp. 281-303. doi:10.1007/s11368-009-0103-z

[8] J. H. R. Gee, B. D. Smith, K. M. Lee and S. W. Griffiths, "The Ecological Basis of Freshwater Pond Management for Biodiversity," Aquatic Conservation: Marine and Freshwater Ecosystems, Vol. 7, No. 2, 1998, pp. 91-104. doi:10.1002/(SICI)1099-0755(199706)7:2<91::AID-AQC 221>3.0.CO;2-O

[9] C. A. Frissell, W. J. Liss, C. E. Warren and M. D. Hurley, "A Hierarchical Framework for Stream Habitat Classification: Viewing Streams in a Watershed Context," Environmental Management, Vol. 10, No. 2, 1986, pp. 199214. doi:10.1007/BF01867358

[10] W. H. Lowe, G. E. Likens and M. E. Power, "Linking Scales in Stream Ecology,” BioScience, Vol. 56, No. 7, 2006, pp. 591-597. doi:10.1641/0006-3568(2006)56[591:LSISE]2.0.CO;2

[11] G. C. Poole, "Fluvial Landscape Ecology: Addressing Uniqueness within the River Discontinuum," Freshwater Biology, Vol. 47, No. 4, 2002, pp. 641-660. doi:10.1046/j.1365-2427.2002.00922.x

[12] L. Benda, N. L. Poff, D. Miller, T. Dunne, G. Reeves, G. Pess and M. Pollock, "The Network Dynamics Hypothesis: How Channel Networks Structure Riverine Habitats,” BioScience, Vol. 54, No. 5, 2004, pp. 413-427. doi:10.1641/0006-3568(2004)054[0413:TNDHHC]2.0.C O;2

[13] W. H. Renwick, S. V. Smith, J. D. Bartley and R. W. Buddemeier, "The Role of Impoundments in the Sediment Budget of the Conterminous United States," Geomorphology, Vol. 71, No. 1, 2005, pp. 99-111. doi:10.1016/j.geomorph.2004.01.010

[14] C. D. Arp, M. N. Gooseff, M. A. Baker and W. Wurtsbaugh, "Surface-Water Hydrodynamics and Regimes of a Small Mountain Stream-Lake Ecosystem,” Journal of Hydrology, Vol. 329, No. 3, 2006, pp. 500-513. doi:10.1016/j.jhydrol.2006.03.006
[15] A. M. Gurnell, “The Hydrogeomorphological Effects of Beaver Dam-Building Activity,” Progress in Physical Geography, Vol. 22, No. 2, 1998, pp. 167-189.

[16] C. J. Woltemade, “Ability of Restored Wetlands to Reduce Nitrogen and Phosphorus Concentrations in Agricultural Drainage Water,” Journal of Soil and Water Conservation, Vol. 55, No. 3, 2000, pp. 303-309.

[17] J. Persson, N. L. G. Somes and T. H. F. Wong, "Hydraulics Efficiency of Constructed Wetlands and Ponds," Water Science \& Technology, Vol. 40, No. 3, 1999, pp. 291300. doi:10.1016/S0273-1223(99)00448-5

[18] J. Koskiaho, "Flow Velocity Retardation and Sediment Retention in Two Constructed Wetland-Ponds," Ecological Engineering, Vol. 19, No. 5, 2003, pp. 325-337. doi:10.1016/S0925-8574(02)00119-2

[19] A. K. Myers, A. M. Marcarelli, C. D. Arp, M. A. Baker and W. A. Wurtsbaugh, "Disruptions of the Stream Sediment Size and Stability by Lakes in Mountain Watersheds: Potential Effects on Periphyton Biomass," Journal of the North American Benthological Society, Vol. 26, No. 3, 2007, pp. 390-400. doi:10.1899/06-086.1

[20] T. E. Lisle and J. Lewis, "Effects of Sediment Transport on Survival of Salmonid Embryos in a Natural Stream: A Simulation Approach," Canadian Journal of Fisheries and Aquatic Sciences, Vol. 49, No. 11, 1992, pp. $2337-$ 2344. doi:10.1139/f92-257

[21] K. N. Brooks, P. F. Ffolliott, H. M. Gregersen and L. F. DeBano, "Hydrology and the Management of Watersheds," 3rd Edition, Iowa State University Press, Ames, 2003.

[22] J. R. Maxted, C. H. McCready and M. R. Scarsbrook, "Effects of Small Ponds on Stream Water Quality and Macroinvertebrate Communities,” New Zealand Journal of Marine and Freshwater Research, Vol. 39, No. 5, 2005, pp. 1069-1084. doi:10.1080/00288330.2005.9517376

[23] B. W. Webb, D. M. Hannah, R. D. Moore, L. E. Brown and F. Nobilis, "Recent Advances in Stream and River Temperature Research,” Hydrological Processes, Vol. 22, No. 7, 2008, pp. 902-918. doi:10.1002/hyp.6994

[24] D. Caissie, "The Thermal Regime of Rivers: A Review," Freshwater Biology, Vol. 51, No. 8, 2006, pp. 1389-1406. doi:10.1111/j.1365-2427.2006.01597.x

[25] R. Gu and H. G. Stefan, "Stratification Dynamics in Wastewater Stabilization Ponds," Water Research, Vol. 29, No. 8, 1995, pp. 1909-1923. doi:10.1016/0043-1354(95)00011-9

[26] J. Polorny and S. Bjork, "Development of Aquatic Macrophytles in Shallow Lakes and Ponds," Wetlands: Ecology, Conservation and Management, Vol. 3, 2010, pp. 3743.

[27] M. R. Vinson, "Long-Term Dynamics of an Invertebrate Assemblage Downstream from a Large Dam,” Ecological Applications, Vol. 11, No. 3, 2001, pp. 711-730. doi:10.1890/1051-0761(2001)011[0711:LTDOAI]2.0.CO ;2

[28] R. L. Vannote, G. W. Minshall, K. W. Cummins, J. R. Sedell and C. E. Cushing, "The River Continuum Concept," Canadian Journal of Fisheries and Aquatic Sciences, Vol. 37, No. 1, 1980, pp. 130-137. doi:10.1139/f80-017 
[29] M. P. Jones and W. F. Hunt, "Effect of Storm-Water Wetlands and Wet Ponds on Runoff Temperature in Trout Sensitive Waters," Journal of Irrigation and Drainage Engineering, Vol. 136, No. 9, 2010, pp. 656-661. doi:10.1061/(ASCE)IR.1943-4774.0000227

[30] B. O. L. DeMars, J. R. Manson, J. S. Ólafsson, G. M. Gislason, R. Gudmundsdottír, G. Woodward, J. Reiss, D. E. Pichler, J. J. Rasmussen and N Friberg, "Temperature and the Metabolic Balance of Streams," Freshwater Biology, Vol. 56, No. 6, 2011, pp. 1106-1121. doi:10.1111/j.1365-2427.2010.02554.x

[31] J. H. Selong, T. E. McMahon, A. V. Zale and F. T. Barrows, "Effect of Temperature on Growth and Survival of Bull Trout, with Application of an Improved Method for Determining Thermal Tolerance in Fishes," Transactions of the American Fisheries Society, Vol. 130, No. 6, 2001, pp. 1026-1037. doi:10.1577/1548-8659(2001)130<1026:EOTOGA $>2.0 . C$ $\underline{\mathrm{O} ; 2}$

[32] H. Gosnell, J. H. Haggerty and P. A. Byorth, "Ranch Ownership Change and New Approaches to Water Resource Management in Southwestern Montana: Implications for Fisheries," Journal of the American Water Resources Association, Vol. 43, No. 4, 2007, pp. 990-1003. doi:10.1111/j.1752-1688.2007.00081.x

[33] P. A. Hsieh, W. Wingle and R. W. Healy, "VS2DI-A Graphical Software Package for Simulating Fluid Flow and Solute or Energy Transport in Variably Saturated Porous Media,” US Geological Survey Water-Resources Investigations Report, Vol. 99, No. 4130, 2000, p. 16.

[34] J. Vymazal, "Removal of Nutrients in Various Types of Constructed Wetlands," Science of the Total Environment, Vol. 380, No. 1, 2007, pp. 48-65. doi:10.1016/j.scitotenv.2006.09.014

[35] N. Pacini, D. M. Harper, V. Ittekott, C. Humborg and L. Rahm, “Nutrient Processes and Consequences,” In: D. M. Harper, M. Zalewski and N. Pacini, Eds., Ecohydrology: Processes, Models and Case Studies, CAB International, Cambridge, 2008, pp. 30-45.

[36] K. M. Johannesson, J. L. Andersson and K. S. Tonderski, "Efficiency of a Constructed Wetland for Retention of Sediment-Associated Phosphorus," Hydrobiologia, Vol. 674, No. 1, 2011, pp. 179-190. doi:10.1007/s10750-011-0728-y

[37] G. W. Fairchild and D. J. Velinsky, "Effects of Small Ponds on Stream Water Chemistry," Lake and Reservoir Management, Vol. 22, No. 4, 2006, pp. 321-330. doi:10.1080/07438140609354366

[38] W. K. Dodds and J. J. Cole, "Expanding the Concept of Trophic State in Aquatic Ecosystems: It's Not just the Autotrophs,” Aquatic Sciences, Vol. 69, No. 4, 2007, pp. 427-439. doi:10.1007/s00027-007-0922-1

[39] J. H. Selong and L. A. Helfrich. "Impacts of Trout Culture Effluent on Water Quality and Biotic Communities in Virginia Headwater Streams," The Progressive Fish-Culturist, Vol. 60, No. 4, 1998, pp. 247-262. doi:10.1577/1548-8640(1998)060<0247:IOTCEO >2.0.C $\underline{\mathrm{O} ; 2}$

[40] B. Oertli, R. Céréghino, A. Hull and R. Miracle, "Pond
Conservation: From Science to Practice,” Hydrobiologia, Vol. 634, No. 1, 2009, pp. 1-9. doi:10.1007/s10750-009-9891-9

[41] B. Oertli, D. A. Joye, E. Castella, R. Juge, D. Cambin, and J. Lachavanne, "Does Size Matter? The Relationship between Pond Area and Biodiversity," Biological Conservation, Vol. 104, No. 1, 2002, pp. 59-70. doi:10.1016/S0006-3207(01)00154-9

[42] R. K. Didham, J. M. Tylianakis, N. J. Gemmell, T. A. Rand and R. M. Ewers, "Interactive Effects of Habitat Modification and Species Invasion on Native Species Decline," Trends in Ecology \& Evolution, Vol. 22, No. 9, 2007, pp. 489-496.

[43] M. B. Allen and E. P. Bergersen, "Factors Influencing the Distribution of Myxobolus cerebralis, the Causative Agent of Whirling Disease, in the Cache la Poudre River, Colorado," Diseases of Aquatic Organisms, Vol. 49, No. 1, 2002, pp. 51-60. doi:10.3354/dao049051

[44] J. C. Burckhardt, W. A. Hubert, R. Gipson, D. Zafft, K. Gelwicks, D. Hawk and D. Money, "The Effects of Habitat Features on Whirling Disease Infection across a Rocky Mountain Watershed,” Ph.D. Dissertation, University of Wyoming, Laramie, 2002.

[45] R. B. Nehring, K. G. Thompson, D. L. Shuler and T. M. James. "Using Sediment Core Samples to Examine the Spatial Distribution of Myxobolus cerebralis Actinospore Production in Windy Gap Reservoir, Colorado,” North American Journal of Fisheries Management, Vol. 23, No. 2, 2003, pp. 376-384. doi:10.1577/1548-8675(2003)023<0376:USCSTE $>2.0 . C$ $\mathrm{O} ; 2$

[46] E. R. Vincent, "Effect of Changing Water Flows on Infection Rates in Rainbow Trout," Eighth Annual Whirling Disease Symposium, Denver, 13-15 February 2002, pp. 43-44.

[47] M. G. Knutson, W. B. Richardson, D. M. Reineke, B. R. Gray, J. R. Parmelee and S. E. Weick. "Agricultural Ponds Support Amphibian Populations,” Ecological Applications, Vol. 14, No. 3, 2004, pp. 669-684. doi:10.1890/02-5305

[48] I. C. Olsson, L. A. Greenberg and A. G. Eklöv, "Effect of an Artificial Pond on Migrating Brown Trout Smolts," North American Journal of Fisheries Management, Vol. 21, No. 3, 2001, pp. 498-506.

doi:10.1577/1548-8675(2001)021<0498:EOAAPO>2.0.C $\underline{\mathrm{O} ; 2}$

[49] W. J. Mitsch and J. W. Day, “Thinking Big with WholeEcosystem Studies and Ecosystem Restoration-A Legacy of H.T. Odum,” Ecological Modelling, Vol. 178, No. 1, 2004, pp. 133-155. doi:10.1016/j.ecolmodel.2003.12.038

[50] W. K. Michener, “Quantitatively Evaluating Restoration Experiments: Research Design, Statistical Analysis, and Data Management Considerations,” Restoration Ecology, Vol. 5, No. 4, 1997, pp. 324-337. doi:10.1046/j.1526-100X.1997.00546.X

[51] G. W. Kling, G. W. Kipphut, M. M. Miller and W. J. O'Brien, "Integration of Lakes and Streams in a Landscape Perspective: The Importance of Material Processing 
on Spatial Patterns and Temporal Coherence," Freshwater

Biology, Vol. 43, No. 3, 2000, pp. 477-497.

doi:10.1046/j.1365-2427.2000.00515.x 